\title{
Long-Term 32-Hours Continuous Shifts Increases Progesterone, IL-1 $\beta$, TNF- $\alpha$, IL-6, Eosinophil Count and Attention Performance in Female Pediatric Resident
}

\author{
Uzun Süreli 32 Saatlik Aralıksız Vardiyalar, Kadın Pediatri Asistanında \\ Progesteron, II-1 $\beta$, Tnf-a, II-6, Eozinofil Sayısı ve Dikkat Performansını \\ Artırır
}

\author{
(1)Pınar Çakan', (1)Sedat Yıldız² \\ 'Department of Physiology, University of Health Sciences, Faculty of Medicine, Istanbul, Turkey \\ ${ }^{2}$ Department of Physiology, Inonu University, Faculty of Medicine, Malatya, Turke
}

Copyright@Author(s) - Available online atwww.dergipark.org.tr/tr/pub/medr

Content of this journal is licensed under a Creative Commons Attribution-NonCommercial 4.0 International License.

\begin{abstract}
Aim: The study aimed at assessing effects of long-term 32-hours continuous shifts on leptin, melatonin, sex hormones, IL-1 $\beta$, TNF- $a$, IL-6, hematological parameters, sleep quality and attention performance in female pediatric residents (FPR).

Materials and Methods: FPR working under 32 hours continuous shifts (08:00-08:00h after 08:00-17:00h, $\mathrm{n}=10)$ were compared to female health professionals working in day-time hours $(08: 00-16: 00 h, n=10)$. Vital parameters, glucose, leptin, melatonin, estrogen, progesterone, IL-1 $\beta$, TNF- $\alpha$, and IL- 6 concentrations, complete blood count (CBC) and erythrocyte sedimentation rate (ESR) were measured. The participants were also requested to fill in sleep quality questionnaires and visual attention test.

Results: In the study; eosinophil ratio $(p=0.015)$, hemoglobin $(p=0.010)$, hematocrit $(p=0.012)$, progesterone $(p=0.008)$, TNF-a, $(p=0.000)$, IL-1 beta and ( $p=0.003)$ IL-6 levels $(p=0.000)$ were found significantly higher in FPR. In addition, it was found that FPR had difficulty in waking up in the mornings $(p=0.000)$, had bad dreams $(p=0.040)$, and had poor sleep quality $(p=0.010)$. FPR had better attention performance $(\mathrm{p}=0.000)$.

Conclusion: Although attention performance was higher in FPR, data suggest that long-term continuous 32-hour shift system activates inflammatory response, disturbs ovarian steroid production and reduces sleep quality. Alltogether, these may culminate in inflammatory diseases or reproductive problems.
\end{abstract}

Keywords: Sleep, long-term continuous shift system, female, cytokine, hormone, hematological parameters

Öz

Amaç: Çalışmada, kadın pediatri asistanlarında uzun süreli 32 saatlik aralıksız vardiyaların leptin, melatonin, seks hormonları, IL-1 $\beta$, TNF-a, IL-6, hematolojik parametreler, uyku kalitesi ve dikkat performansı üzerine etkilerininin değerlendirilmesi amaçlamıştır. FPR). Materyal ve Metot: 32 saat sürekli vardiyada (08:00-08:00 sonrası 08:00-17:00, $n=10)$ çalışan FPR, gündüz saatlerinde (08:00-16: 00 saat, $n=10$ ) çalışan kadın sağlık profesyonelleri ile karşılaştırılmıştır.

Bulgular: Çalışmada; eozinofil oranı $(p=0.015)$, hemoglobin $(p=0.010)$, hematokrit $(p=0.012)$, progesteron $(p=0.008), T N F a,(p=0.000)$, IL-1beta ve $(p=0.003)$ IL-6 düzeyleri $(p=0.000)$ FPR'de anlamlı olarak yüksek bulundu. Ayrıca FPR'nin sabahları uyanmakta güçlük çektiği $(p=0,000)$, kötü rüyalar gördüğü $(p=0,040)$ ve uyku kalitesinin kötü olduğu $(p=0,010)$ bulundu. FPR daha iyi dikkat performansı gösterdi $(p=0.000)$.

Sonuç: FPR'de dikkat performansı daha yüksek olmasına rağmen, veriler uzun süreli sürekli 32 saatlik vardiya sisteminin inflamatuar yanıtı aktive ettiğini, over steroid üretimini bozduğunu ve uyku kalitesini azalttığını göstermektedir. Hep birlikte, bunlar iltihaplı hastalıklar veya üreme sorunları ile sonuçlanabilir.

Anahtar Kelimeler. Uyku, uzun süreli aralıksız vardiya sistemi, kadın, sitokin, hormon, hematolojik parametreler

Geliş Tarihi / Received: 28.07.2021 Kabul Tarihi / Accepted: 07.08.2021

Sorumlu Yazar /Corresponding Author. Pınar Çakan, Department of Physiology, University of Health Sciences,

Faculty of Medicine, Istanbul, Turkey, E-mail: pinar.cakan@sbu.edu.tr 


\section{INTRODUCTION}

Thetwenty-four-hourservicehasbecomeanindispensable part of working organizations due to the ever-changing demands of modern societies (1). Since the national health services provide 24 hour service for patients, the shift system and night work have become an important part of these organizations (2). Today, one in five working in Europe works on a night shift lasting more than twenty hours (3). In 1990, the international labor organization set new and radical standards for working organizations due to the negative impact of long or abnormal working hours on health (3). Although shift work is economically and socially important, disrupts the normal functioning of biological rhythms and contributes to social problems and the deterioration of sleep and health of shift workers (4) and negatively impact work performance (5).

Sleep is known to be important forh health and functional capacity (6). Sleep disturbance is a significant problem for shift workers due to the prevalence rate and the occupational and health consequences with which it is associated (7). Shift and night work may have negative effects on health, possibly due to the effects of sleepwake cycle, eating, exercise behaviors, thermogenesis, hormone secretion and blood pressure levels (8). People working in shift system; increased blood pressure and heart rate reduction (9), increased cardiovascular morbidity and mortality and gastrointestinal disease rates (10). Sleepers and reproductive dysfunctions (10), lower working performance and risk of occupational accidents were found to be high in people working on night shifts (11). In their study, Born et al. found increased levels of hemoglobin and hematocrit, leucocyte, red blood cells, platelet counts, monocytes, natural killer cells and subgroups of lymphocytes in people with sleep deprivation (12). Plasma IL-6 and TNF-a levels were found to be high in all sleep-deprived nights (13). The shift system or long hours of work can cause problems by severely disrupting family and marital responsibilities (3). The effects of shift work on the human body may vary according to gender (14). The negative effects of the shift system, and especially the night shift on women, may be higher than their male counterparts due to home responsibilities, menstrual cycle deterioration and stress (3).

When we examine the publications about shifts up to the present, we have not found any studies investigating the long-term shift programs such as 32 hours. Recent research has focused on the potential health effects of shift work on sleep deprivation, cardiovascular disease, and metabolic disorders. (15). The present study, effects of 32 hours continuous shifts in FPR on their leptin, melatonin, sex hormones, IL-1 $\beta$, TNF- $\alpha$, IL-6, hematological and vital parameters, sleep quality and attention performance were examined.

\section{MATERIAL AND METHOD}

\section{Ethical consent and participants}

Approval for the study was obtained from the local ethics committee (Malatya Clinical Ethics Committee, No:2016/197). The participants consisted of female pediatric resident (FPR, 32 hours continuous shifts) and female health care professional (nurses, day-time workers) and working in the hospital. Groups were matched for menstrual phase. The study included healthy, regular cycling and non-smokers aged between 18 and 40 years.

\section{Experimental design}

The research consists of two groups of female participants working in the hospital: day-time workers (called as daytime shifters, $n=10,08: 00-16: 00 \mathrm{~h}, 37 \pm 1$ year-old, $71 \pm 3$ $\mathrm{kg}, 166 \pm 2 \mathrm{~cm}$ ) and female pediatric resident (called as 32 hours continuous shifts, $n=10$, from $08: 00 \mathrm{~h}$ to $17: 00$ $\mathrm{h}$ in the day after, $29 \pm 1$ year-old, $65 \pm 5 \mathrm{~kg}, 158 \pm 7 \mathrm{~cm}$ ) as outlined in Figure 1. Their vital parameters such as blood pressure (systolic and diastolic), pulse rate, respiratory rate, skin temperatures (forehead) and blood glucose levels were measured at 08:00, 16:00, 08:00 and 16:00 $\mathrm{h}$ during the 32-h continuous shift. These time points were similar for day time-shifters. FPR, started a normal shift in the next day following a $16 \mathrm{~h}$ resting period and above parameters were re-assessed at 08:00 $\mathrm{h}$ in the beginning of next morning. Blood samples were taken at $08: 00 \mathrm{~h}$ at the end of 16 hours of rest after 32-hours of work schedule and were used for whole blood hematological parameters and erythrocyte sedimentation rate (ESR). Concentrations of cytokines (IL-1 $\beta$, TNF- $a$, IL-6) and hormones (leptin, melatonin, estradiol, progesterone) in blood plasma were measured. Questionnaires [Pittsburgh Sleep Quality Index (PSQI), Karolinska Sleep Questionnaire (KSQ), State and Trait Anxiety Inventory (STAI)] and attention performance test (tracking test) were used in the study.

\section{Evaluation of vital findings}

Prior to evaluation of vital signs, participants rested in a sitting position for 5 minutes. Respirations and pulse rates were counted for 15 seconds and multiplied by four to calculate their rate per minute. For this purpose, pulse rate measurement was performed by placing three fingers between the bone and tendon on the radial artery in the participants, and chest movement was used for respiratory rate determination. Arterial blood pressure measurement was done indirectly using an automatic digital blood pressure monitor (Omron, M6 comfort, China). Proximal skin temperature was measured using a non-contact (without touching the skin) infrared digital thermometer (Mesilife, DT-8806, Mesitaş, Turkey). Blood glucose level was measured before the main meal by blood glucose monitoring system (Clever Chek, TD-4222, Germany) using venous blood.

\section{Venous blood collection}

Venous blood was drawn by a $10 \mathrm{ml}$ injector with a 
20-gauge needle and then transferred into two vacuum tubes with $\mathrm{K} 3$ ethylenediaminetetraacetic acid (EDTA). One of the tubes was centrifuged to obtain plasma, while the other tube was sent to the laboratory to determine the complete blood count (CBC) and erythrocyte sedimentation rate (ESR). CBC parameters were measured (Table 2 and Table 3).

\section{Hormone and cytokine ELISA protocol}

Plasma melatonin, leptin, estradiol, progesterone, TNF- $a, I L-1 \beta$ and IL- 6 concentrations were measured by commercial enzyme immunoassay test kits (Fine Test, China). Plates were read using a microplate reader (Biotek, Synergy HT, USA) at $450 \mathrm{~nm}$.

\section{Visual trial test}

The visual attention level of the participants was determined by means of a mark-making test consisting of numbers from 1 to 25 randomly distributed on an A4 paper. After the participants were informed about the test procedure, they were asked to complete the test. The first and last numbers were marked with a circle, making it easier for the participants to start and stop. With the aid of a stopwatch, the time used to complete the trail making test was recorded.

\begin{tabular}{|c|c|c|c|}
\hline Vital parameters & $\begin{array}{c}32 \mathrm{~h} \\
\text { continous }\end{array}$ & $\mathbf{p}$ & \\
\hline Respiration (number/min) & $21 \pm 1$ & $22.7 \pm 0.8$ & 0.137 \\
\hline Pulse (heart beat/min) & $74 \pm 3$ & $76.3 \pm 1.8$ & 0.488 \\
\hline Systolic Blood Pressure (mmHg) & $106 \pm 3$ & $98.0 \pm 2.7$ & 0.057 \\
\hline $\begin{array}{l}\text { Diastolic Blood Pressure } \\
(\mathrm{mmHg})\end{array}$ & $72 \pm 2$ & $68.9 \pm 2.6$ & 0.420 \\
\hline Glucose (mg/dl) & $100 \pm 4$ & $99.8 \pm 3.0$ & 0.905 \\
\hline Body Temperature (oC) & $36.5 \pm 0.1$ & $36.5 \pm 0.1$ & 0.853 \\
\hline
\end{tabular}

\begin{tabular}{|c|c|c|c|}
\hline CBC parameter & Day-time work & $\begin{array}{l}32 \mathrm{~h} \text { continous } \\
\text { shift }\end{array}$ & $\mathbf{p}$ \\
\hline Leukocyte \# (109/L) & $6.770 \pm 0.427$ & $7.484 \pm 0.559$ & 0.323 \\
\hline Erythrocyte \# (1012/L) & $4.491 \pm 0.106$ & $4.69 \pm 0.08$ & 0.146 \\
\hline Haemoglobin (g/dL) & $12.1 \pm 0.3$ & $13.3 \pm 0.2$ & 0.010 \\
\hline Hematocrit (\%) & $37.6 \pm 0.9$ & $40.7 \pm 0.6$ & 0.012 \\
\hline $\mathrm{MCH}(p g)$ & $27.1 \pm 0.6$ & $28.3 \pm 0.5$ & 0.128 \\
\hline $\mathrm{MCHC}(\mathrm{g} / \mathrm{dL})$ & $32.3 \pm 0.5$ & $32.6 \pm 0.3$ & 0.597 \\
\hline RDW (\%) & $13.7 \pm 0.4$ & $13.2 \pm 0.1$ & 0.203 \\
\hline РCТ (\%) & $0.3 \pm 0.0$ & $0.3 \pm 0.0$ & 0.829 \\
\hline MPV (fL) & $11.1 \pm 0.3$ & $11.0 \pm 0.2$ & 0.803 \\
\hline PDW (\%) & $13.6 \pm 0.8$ & $13.5 \pm 0.5$ & 0.849 \\
\hline NRBC \# & $0.001 \pm 0.001$ & $0.001 \pm 0.001$ & 1.100 \\
\hline NRBC \% & $0.010 \pm 0.010$ & $0.010 \pm 0.010$ & 1.100 \\
\hline MCV (fL) & $83.8 \pm 1.1$ & $86.8 \pm 1.3$ & 0.101 \\
\hline Platelet count (109/L) & $284.2 \pm 17.0$ & $281.9 \pm 21.6$ & 0.934 \\
\hline \multicolumn{4}{|c|}{$\begin{array}{l}\text { MCH: Mean corspuscular hemoglobin } \\
\text { MCHC: Mean corpuscular hemogrlobin concentration } \\
\text { RDW: Red cell distribution width } \\
\text { PCT: Platecrite } \\
\text { MPV: Mean platelet volüme } \\
\text { PDW: Platelet distribution width } \\
\text { NRBC: Nucleated red blood cell } \\
\text { MCV: Mean corpuscular volume }\end{array}$} \\
\hline
\end{tabular}

Table 3. Leukocyte formula and erythrocyte sedimentation rate in women working in different shift types (day-time work and 32 hours continuous shifts). Values are presented as mean $₫$ standard error.

$\begin{array}{lccc}\text { Vital parameters } & \text { Day-time work } & \mathbf{3 2 ~ h} \text { continous shift } & \text { p } \\ \text { Lymphocyte Count \# (109/L) } & 2.074 \pm 0.172 & 2.524 \pm 0.299 & 0.208 \\ \text { Percentage of lymphocytes \% } & 31.4 \pm 2.7 & 33.5 \pm 2.3 & 0.563 \\ \text { Number of monocytes\#(109/L) } & 0.484 \pm 0.030 & 0.505 \pm 0.044 & 0.699 \\ \text { Percentage of monocytes \% } & 7.3 \pm 0.5 & 6.8 \pm 0.5 & 0.469 \\ \text { Neutrophil count \# (109/L) } & 4.065 \pm 0.422 & 4.2 \pm 0.3 & 0.798 \\ \text { Neutrophil percentage \% } & 59.1 \pm 2.9 & 56.5 \pm 2.1 & 0.465 \\ \text { Number of basophils (109/L) } & 0.051 \pm 0.006 & 0.056 \pm 0.008 & 0.633 \\ \text { Percent of basophil \% } & 0.8 \pm 0.1 & 0.7 \pm 0.1 & 0.883 \\ \text { Eosinophil count \# (109/L) } & 0.091 \pm 0.011 & 0.190 \pm 0.035 & 0.015 \\ \text { Percentage of eosinophils \% } & 1.4 \pm 0.1 & 2.5 \pm 0.4 & 0.013 \\ \text { Neutrophil / lymphocyte ratio } & 2.2 \pm 0.2 & 1.8 \pm 0.5 & 0.480 \\ \text { Sedimentation (mm/h) } & 11.7 \pm 3.5 & 7.4 \pm 2.6 & 0.338\end{array}$




\section{Statistical analyses}

Statistical analyzes were performed using statistical software (Minitab 17, USA). Anderson-Darling test was used to control the normal distribution of the data. Data that did not show normal distribution were converted to log 10 data for normal distribution. Normally distributed data after this transformation were analyzed by Student's t-test. Non-normally distributed data and non-parametric data were analyzed using the Kruskal-Wallis test. Pearson test or Spearman Rho were used for normal or nonnormally distributed data, respectively, for correlation analysis. $p<0.05$ was considered statistically significant.

\section{RESULT}

Demographic characteristics, vital signs, hematological parameters, inflammatory cytokine responses, metabolic and reproductive hormone levels, attention test findings, sleep parameters and regression analysis values are presented below.

\section{Vital signs}

Vital parameters are presented in Table 1. There was no difference between the groups in terms of respiratory rate, blood pressure, pulse rate, blood glucose and proximal skin temperature ( $p>0.05)$.

\section{Hematological findings}

$\mathrm{CBC}$ values are presented in Table 2 by group. Number of leukocyte, erythrocytes, number NRBC, $\mathrm{MCH}, \mathrm{MCHC}$, RDW, PCT, MPV, PDW, MCVand platelet were not different among the groups $(p>0.05)$. However, we found that women working in 32 hours continuous shifts had higher hemoglobin concentration $(13.3 \pm 0.2$ vs $12.1 \pm 0.3$; $p=0.010)$, higher hematocrit concentration $(40.7 \pm 0.6$ vs 37.6 $\pm 0.9 ; p=0.012$; Table 2).

The leukocyte, neutrophil/lymphocyte ratio, and sedimentation numbers and percentages are presented in Table 3 by group. Counts of lymphocyte, monocytes, neutrophil, basophils and percentages of lymphocytes, monocytes, neutrophils and basophils did not differ among the groups $(p>0.05)$. Moreover, neutrophil/ lymphocyte ratio and sedimentation did not differ between groups ( $p>0.05)$. However, eosinophil count was higher in 32 hours continuous shifts $(0.190 \pm 0.035)$ than day-time $(0.091 \pm 0.015 ; p=0.011$; Table 3$)$; percentage of eosinophils was higher in 32 hours continuous shifts (2.5 \pm 0.4$)$ compared to day-time $(1.4 \pm 0.1 ; p=0.013$; Table $3)$.

\section{Plasma melatonin, leptin, estrogen and progesterone enzymeimmunoassays}

Plasma melatonin, leptin, estrogen and progesterone concentrations of the experimental groups are shown in Figure 2. Melatonin, leptin and estrogen concentrations did not differ among the groups ( $p>0.05$; Figure $2 a$, Figure $2 \mathrm{~b}$, Figure $2 \mathrm{c}$ respectively). Progesterone concentration was higher in 32 hours continuous shifts $(5,433 \pm 1,60)$ than day-time work group $(3,533 \pm 0,7 ; p=0.008$, Figure $2 d)$.
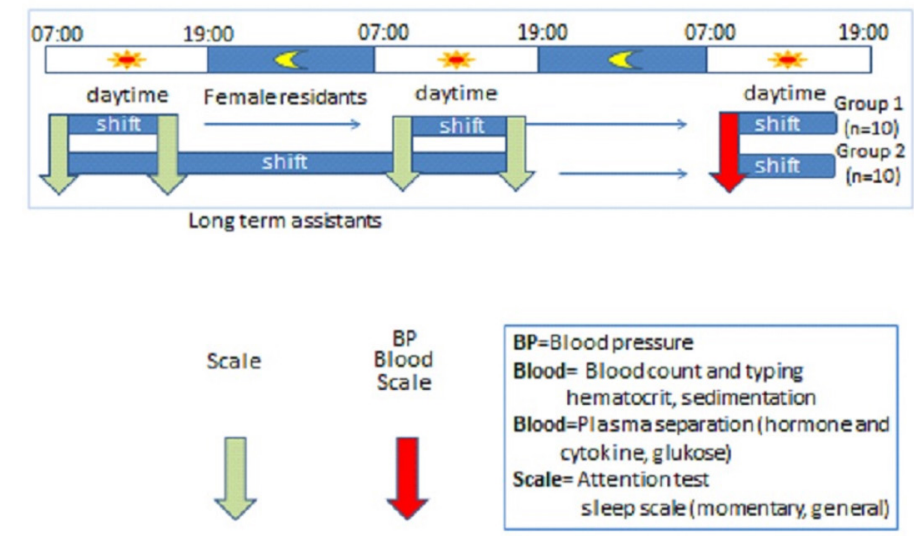

Figure 1. Design of the study. The women in Group $1(n=10)$ had a normal day-time work while Group 2 had a 32 hours continuous shift $(n=10)$ followed by a normal day- time work schedule. In the beginning and at the end of each daytime shift, vital parameters such as blood pressure (systolic and diastolic), pulse rate, respiratory rate, body temperature and blood glucose were measured. At the end of 16 hours of rest after 32-hours of work, blood samples were taken for the measurements of cytokines (IL-1beta, TNF-alpha, IL-6), hormones (leptin, melatonin, estrogen, progesterone), whole blood hematological parameters and erythrocyte sedimentation rate (ESR). Questionnaires (state and trait anxiety, sleep duration and quality) and attention performance test were also completed by the participants a)

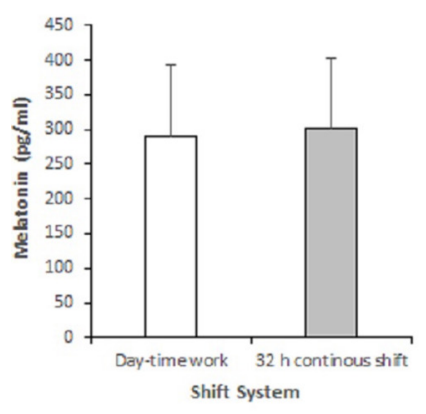

c)

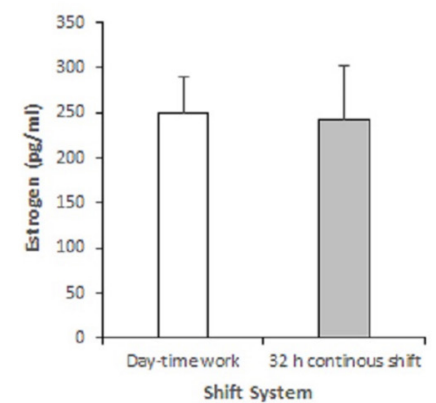

b)

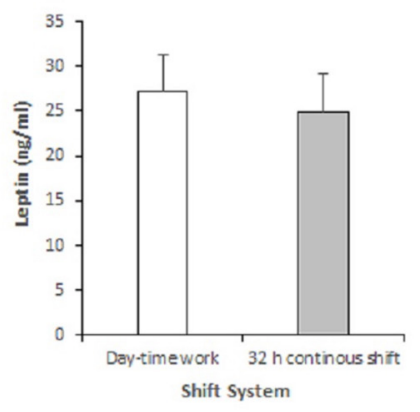

d)

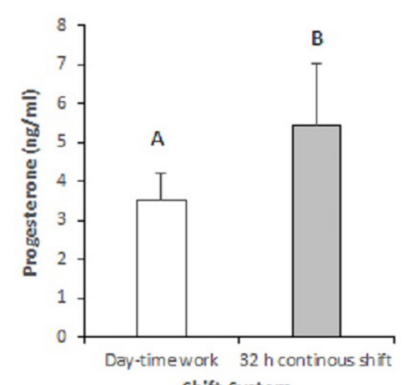

Shift System
Figure 2. Melatonin (a), leptin (b), estrojen (c) and progesterone (d) concentrations in women working in different shift types (day-time work and 32 hours continuous shifts). Values represents as mean \pm standard error. Groups with different capital letters differ significanly

\section{IL-1 $\beta$, TNF- $\alpha$ and IL- 6 enzymeimmunoassays}

Plasma IL-1 $\beta$, TNF- $\alpha$ and IL- 6 concentrations by group are 
presented in Figure 2. IL- 6 levels were higher in 32 hours continuous shifts $(1.62 \pm 0.49)$ than that of day-time shift $(0.48 \pm 0.13 ; p=0.000$; Figure $3 a)$. IL- $1 \beta$ levels were higher in 32 hours continuous shifts $(16.9 \pm 3.02)$ than that of daytime shift $(12.8 \pm 2.11 ; p=0.003$; Figure $3 b)$. TNF-a levels were higher in 32 hours continuous shifts $(4.88 \pm 1.91)$ than that of day-time shift $(2.09 \pm 0.68 ; p=0.000$; Figure 3c).

\section{Attentional performance test evaluations}

Attentional performance assessed via the trail making test did higher in 32 hours continuous shifts $(30.0 \pm 1.43)$ than that of day-time shift $(22.1 \pm 0.8 ; p=0.000$; Figure 4).

\section{Sleep duration and quality}

FPR under 32 hours continuous shifts they have difficulty

a)

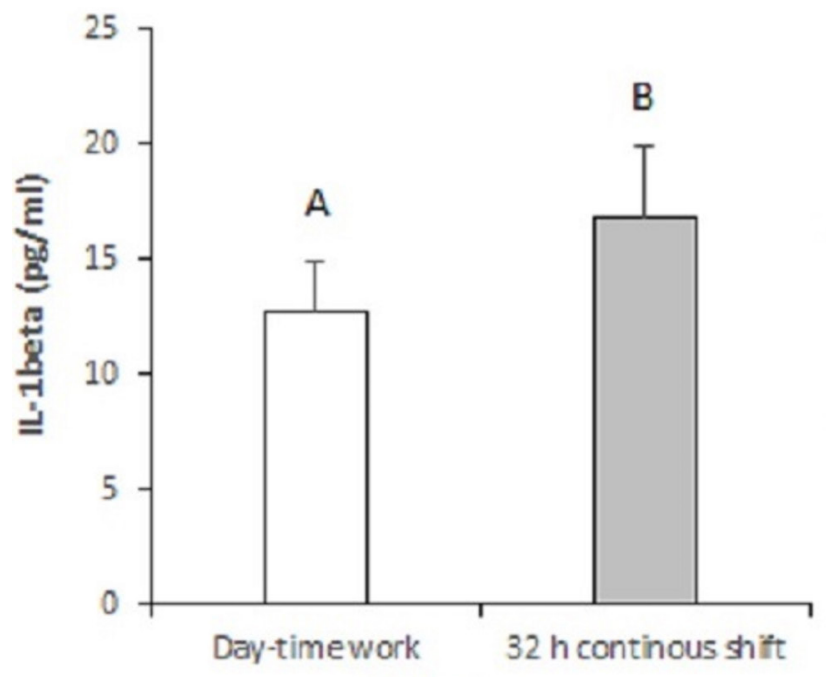

Shift System

c)

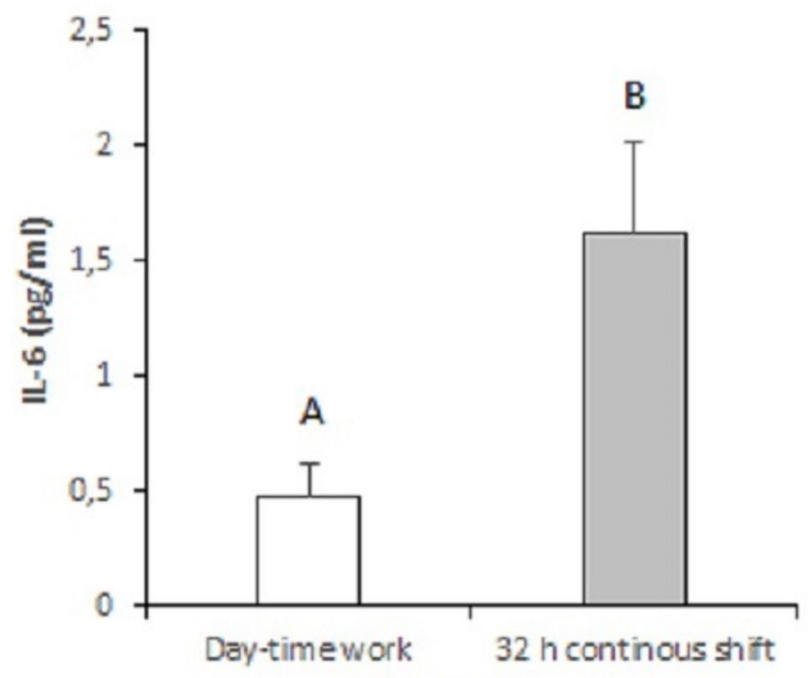

Shift System in awakening $(p=0.000)$, woke up later in the morning $(p=0.009)$, had longer duration of sleep $(p=0.001)$, low quality sleep $(p=0.010)$, had bad dreams and $(p=0.006)$ and $(p=0.040)$ compared to day-time workers.

\section{Correlations}

In the study, the results of regression analysis of attention test, melatonin, leptin, estrogen, progesterone, IL-6, TNF-alpha and IL-1 beta in women working in daytime shift and 32 hours continuous shifts are presented (Table 4). In the study, positive correlation were found between IL- 6 and progesterone $(r 2=0.521, p=0.019)$, IL- 1 beta and IL-6 $(r 2=0.644, p=0.003)$, TNF-alpha and progesterone $(r 2=0.509, p=0.022)$, TNF-alpha and IL-6 $(r 2=0.532, p=0.016)($ Table 4$)$.

b)

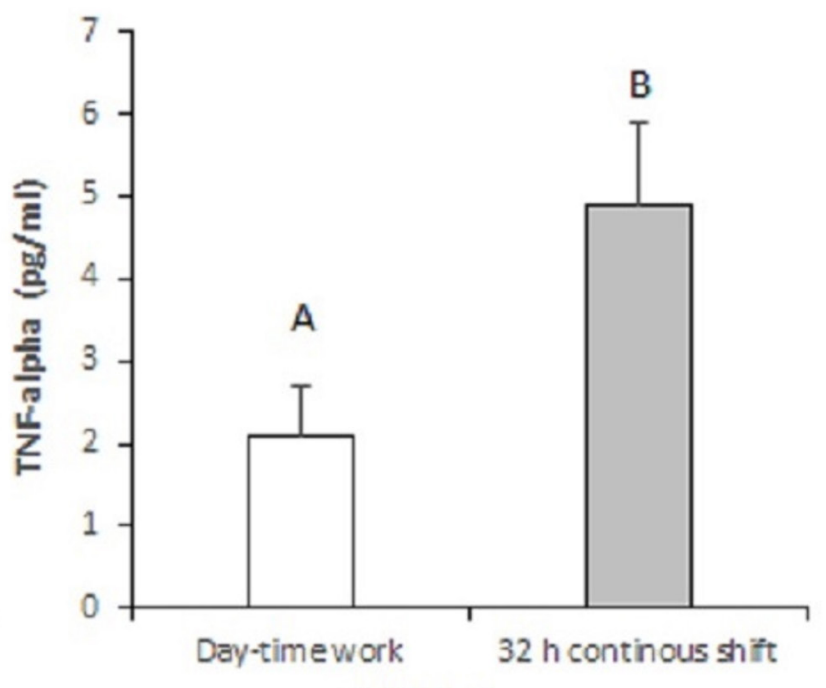

Shift System

Figure 2. IL-1 $\beta$ (a), TNF- $a(b)$ and IL-6 (c) concentrations in women working in different shift types (day-time work and 32 hours continuous shifts). Values represents as mean \pm standard error. Groups with different capital letters differ significanly. 
Table 4. Correlations among hormones and cytokines and duration trial test

\begin{tabular}{|c|c|c|c|c|c|c|c|}
\hline Regression Analysis & Attention Test & Melatonin & Leptin & Estrogen & Progesterone & IL-6 & IL1beta \\
\hline \multirow[t]{2}{*}{ Melatonin } & -0.030 & & & & & & \\
\hline & 0.900 & & & & & & \\
\hline \multirow[t]{2}{*}{ Leptin } & 0.141 & 0.140 & & & & & \\
\hline & 0.552 & 0.557 & & & & & \\
\hline \multirow[t]{2}{*}{ Estrogen } & -0.030 & -0.047 & -0.294 & & & & \\
\hline & 0.901 & 0.843 & 0.209 & & & & \\
\hline \multirow{2}{*}{ Progesterone } & -0.106 & -0.049 & -0.142 & 0.196 & & & \\
\hline & 0.655 & 0.837 & 0.551 & 0.408 & & & \\
\hline \multirow[t]{2}{*}{ IL-6 } & -0.437 & -0.012 & -0.205 & 0.093 & 0.521 & & \\
\hline & 0.054 & 0.961 & 0.386 & 0.697 & 0.019 & & \\
\hline \multirow{2}{*}{ IL-1beta } & -0.112 & -0.016 & 0.007 & 0.043 & 0.406 & 0.644 & \\
\hline & 0.648 & 0.947 & 0.978 & 0.861 & 0.085 & 0.003 & \\
\hline \multirow{2}{*}{ TNF-alpha } & -0.275 & -0.098 & -0.087 & -0.135 & 0.509 & 0.532 & 0.400 \\
\hline & 0.241 & 0.680 & 0.717 & 0.571 & 0.022 & 0.016 & 0.089 \\
\hline
\end{tabular}

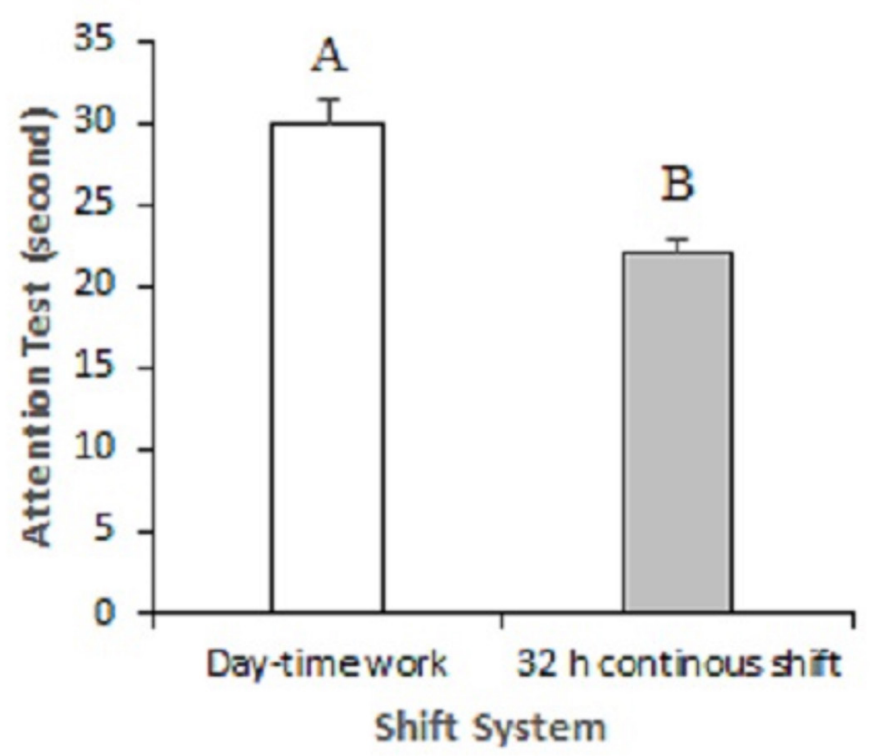

Figure 4. End of the shift trial test durations in women working in different shift types (day-time work and 32 hours continuous shifts). Values represents as mean \pm standard error. Groups with different capital letters differ significanly $(p=0.000)$.

\section{DISCUSSION}

This study compared the 32 hours continuous shifts and day-time shifts in women working in health sector and found out that night shifts and its duration had profound effects on various physiological parameters including CBC parameters, attention performance, sleep duration and quality, inflammatory and hormonal parameters. All these changes suggest that, in long term, there might be dentrimental effects of night-shift works on health the female healthcare workers. Also, it is thought that it may be useful to keep shift schedules short and to include rest periods. Moreover, it is thought that it may be useful to keep shift schedules short and to include rest periods.

\section{Long-term shift system did not affect vital signs}

Heart rate, respiratory rate, blood pressures, body temperature and glucose concentration was within normal limits and did not different between the groups, which is also reported by other shift system (16). However, there are some studies emphasizing that there is a relationship between shift work and development of hypertension and cardiovascular disease (15).

Long-term $32 \mathrm{~h}$ shift was associated with increased hemoglobin, hematocrit and eosinophils

The 32 hours continuous shift system in FPR did not affect the number of red blood cells, white blood cells and platelets. For all that hemoglobin and hematocrit were found to be higher, although within normal range, in FPR who had 32 hours continuous shift system. Coglianese et al. found in their study that high hematocrit might be associated with increased heart disease (17). Sorlie et al. studied the risk of hematocrit on coronary heart disease and found out that high hematocrit level may be an independent potential risk factor contributing to coronary heart disease (18).

The 32 hours continuous shift system in FPR did not affect the number of lymphocytes, neutrophils, basophils and monocytes, but increased the number and percentage of eosinophils. Eosinophils are uncommon white blood cells and their activity is primarily related to the destructive infection and asthma (19). In this study, the high percentage and counts of eosinophils in the women under 32 hours continuous shift system may be indicative of increased allergic sensitivities (20). In addition, the long-lasting sleeplessness and 
non-physiologic working hours may be the contributing factors to increased activity of the immune system (21).

Long-term $32 \mathrm{~h}$ shift system working did not affect plasma melatonin, leptin and estrogen levels but increased progesterone levels

In terms of melatonin level, there was no statistically significant difference between women working in 32 hours continuous shift system and women working in day shift. In the current study, we measured melatonin levels in the most standardized time for both groups (i.e. at 08:00 $\mathrm{h}$ in the next day-time work) as the FPR under 32 hours continuous shift are exposed to light in the other times. But this time point of melatonin measurement also coincided with its lowest diurnal level. Nevertheless, similar to our findings, Sack et al. found no difference in the level of melatonin between shifts and daytime work. They have emphasized that the reason for this may be the development of adaptation (22) and may be applicable in this study as well.

The leptin concentration was similar between the groups. In addition, there was no correlation with body mass index. In fact, it has been reported that shift-work increases body fatness and body mass index (23). In the current study, almost all residents had consciousness about good health and well being. They exercised measures such as walking, avoiding fast-food types, taking high nutritional consumption and taking care not to consume food late. It is probable that these types of measures prevented a higher body fat composition and increased leptin in the current study.

Estrogen concentration was not different between the groups but progesterone concentration was higher in women working in 32 hours continuous shift system. Night shift or shift system may cause different health problems (8), including reproductive problems (24). In women, night shifts are reported to shorten or prolong menstrual cycle, or increase menstrual pain (25), or may be associated with increased risk of miscarriage (26). In the current study, increased progesterone concentration might perturb reproductive function. In line with this, recently, Blake et al (2017) observed that lower progesterone and higher estrogen levels predicted higher assertiveness which safeguards indicrimante mate selectivity (27).

\section{Long-term $32 \mathrm{~h}$ shift system increases plasma IL-1 $\beta$,} TNF- $a$ and IL- 6

In the present study, the levels of IL-6, IL-1beta and TNF-alpha were found to be higher in women working in long-term continuous shift system. Sleep is an important regulator of the immune system (21). Thus sleep deprivation may alter the immune response (28). Therefore, the cytokine level may vary depending on the sleep and wake cycle (29). The studies generally showed an increase in cytokine level after sleep deprivation (30). On the other hand, there were no differences in TNFalpha, IL-6 (31) and IL-1beta among the groups as a result of some studies in which the shift system and daytime workers were compared (31). Although there are different results in literature review regarding shift system and immune functions, it is seen that there is an increase in cytokine level in general judicial shift system employees. Similar results were obtained in the current study. The presence of a strong significant increase in all three of the cytokines in the workers of 32 hours continuous shift system (IL- 6 levels $p=0.000$, Figure $3 a$; IL-1 $\beta$ levels, $p=0.003$, Figure $3 b$; TNF-a levels, $p=0.000$; Figure $3 c$ ) supports the significant negative effects of this shift system on the immune system. Therefore, the long-term continuous shift system seems to be risk for the immune system. Negative consequences on the immune system may lead to serious diseases such as diabetes (32), cardiac diseases (33), obesity (32) and cancer (32). For this reason, care must be taken in the regulation of shift system programs.

\section{Long-term shift system working increased visual attention}

The level of attention was found to be better in women working in 32 hours continuous shift system than in women working in day shifts. In a study on sleep deprivation, it was found that the wakefulness levels of the group who were sleepless and tired during the day were higher than the inpatient group, and this was attributed to the relatively increased sympathetic nervous system activity (34). However, there are studies that find different results. In some studies, it has been emphasized that working in night shifts may have negative effects on performance and increase the risk of accidents (35) and impair cognitive functions (36). However, in the present study, long-term insomnia may have a positive effect on employees. As a matter of fact, the level of attention was found to be much better for night shift workers than for those working at day. Yang et al. similarly they found that there was an increase in attention levels in their study of patients with insomnia (37).

\section{Long-term shift system working increased sleep duration but reduced sleep quality}

In the study, women working in 32 hours continuous shift system compared to working women in day shift; they woke up later, had more bad dreams, had worse sleep quality and were more difficult to wake up. On the other hand, it was determined that women working in 32 hours continuous shift system woke less at night to use the toilet. However, when the opinion of the participants on this condition was obtained, it was found that they did not feel the bladder tension due to the increase in sleep depth due to being very tired. In the night shift workers, tiredness (38), inadequate sleep, decreased sleep quality and efficacy, sleep disturbances (38) are more common than day workers. The findings obtained from the present study are also very similar to the literature data. Therefore, taking into account the number of working years and the total number of seizures per month in the organization of night shift work programs and ensuring appropriate 
rest periods may reduce the potential negative effects on night shift women.

\section{IL-6 was correlated with visual attention, IL-1beta, progesterone and TNF- $a$}

In the present study, a positive relationship between IL-6, IL-1 beta and TNF-alpha suggests that the cytokine stress response may be similar (39). A positive relationship between IL- 6 and TNF-alpha and progesterone suggests that the cytokine response may be related to progesterone in case of insomnia. As a matter of fact, it is emphasized that there may be an interaction between sex hormones and cytokines in some studies (40).

\section{CONCLUSION}

Although it may be considered that there is a positive change in hematolytic parameters and attention test in contrast to expectations in women working in 32-hours continuous shift system, it may be thought that these changes may have occurred as a result of deep stress activation. Indeed, such a shift system appears to increase the levels of cytokines (TNF-alpha, IL-1beta, IL6 ) and progesterone and cause sleep problems. For this reason, it is considered that keeping shift programs as short as possible and adding rest periods to short-term shift programs may be useful.

Financial disclosures: Inonu University, Scientific Research Projects Unit (Project No. 2017/649).

Conflict of Interest: The authors declare that they have no competing interest.

Ethical approval: Ethics committee approval of this study was taken from local Clinical Researches Ethics Committee in accordance with the Declaration of Helsinki (Approval $=2016 / 197)$.

\section{REFERENCES}

1. Brum MCB, Filho FFD, Schnorr CC, et al. Shift work and its association with metabolic disorders. Diabetol Metab Syndr. 2015;7:45.

2. Wilson JL. The impact of shift patterns on healthcare professionals. J Nurs Manag. 2002;10:211-9.

3. Harrington JM. Health effects of shift work and extended hours of work. Occup Environ Med. 2001;58:68-72.

4. Reinhardt ÉL, Fernandes PACM, Markus RP, et al. Night work effects on salivary cytokines TNF, IL-1 $\beta$ and IL-6. Chronobiol Int. 2019;36:11-26.

5. Harrington JM. Shift work and health--a critical review of the literature on working hours. Ann Acad Med Singapore. 1994;23:699-705.

6. Sallinen M, Kecklund G. Shift work, sleep, and sleepiness differences between shift schedules and systems. Scand J Work Environ Health. 2010;36:121-33.

7. Åkerstedt T, Garefelt J, Richter A, et al. Work and Sleep-A Prospective Study of Psychosocial Work Factors, Physical Work Factors, and Work Scheduling. Sleep. 2015;38:112936.
8. Van Someren EJW, Riemersma-Van Der Lek RF. Live to the rhythm, slave to the rhythm. Sleep Med Rev. 2007;11:46584.

9. Lo SH, Lin LY, Hwang JS, et al. Working the night shift causes increased vascular stress and dela-yed recovery in young women. Chronobiol Int. 2010;27:1454-68.

10. Nicol A-M, Botterill JS. On-call work and health: a review. Environ Heal. 2004;3:15.

11. Uehli K, Mehta AJ, Miedinger D, et al. Sleep problems and work injuries: A systematic review and meta-analysis. Sleep Med Rev. 2014;18:61-73.

12. Uthgenannt D, Schoolmann D, Pietrowsky R, et al. Effects of sleep on the production of cytoki-nes in humans. Psychosom Med. 1995;57:97-104.

13. Krueger JM, Majde JA, Rector DM. Cytokines in immune function and sleep regulation. Handb Clin Neurol. 2011;98:229-40.

14. McFarlane SI. Shift work and sleep: medical implications and management. Sleep Med Disord Int J. 2017;1:36-42.

15. Yeom JH, Sim CS, Lee J, et al. Effect of shift work on hypertension: cross sectional study. Ann Occup Environ Med. 2017;29:11.

16. Hublin C, Partinen M, Koskenvuo K, et al. Shift-work and cardiovascular disease: A population-based 22-year followup study. Eur J Epidemiol. 2010;25:315-23.

17. Coglianese EE, Qureshi MM, Vasan RS, et al. Usefulness of the blood hematocrit level to predict development of heart failure in a community. Am J Cardiol. 2012;109:241-5.

18. Sorlie PD, Garcia-Palmieri MR, Costas R, et al. Hematocrit and risk of coronary heart disease: the Puerto Rico Heart Health Program. Am Heart J. 1981;101:456-61.

19. Jacobsen EA, Helmers RA, Lee JJ, et al. The expanding role(s) of eosinophils in health and disea-se. Blood. 2012;120:3882-90.

20. Costello RW, Jacoby DB, Gleich GJ, et al. Eosinophils and airway nerves in asthma. Histol Histo-pathol. 2000;15:8618.

21. Almeida CMO De, Malheiro A. Sleep, immunity and shift workers: A review. Sleep Sci. 2016;9:164-8.

22. Sack RL, Blood ML, Lewy AJ. Melatonin rhythms in night shift workers. Sleep. 1992;15:434-41.

23. Kim M-J, Son $\mathrm{K}-\mathrm{H}$, Park $\mathrm{H}-\mathrm{Y}$, et al. Association between shift work and obesity among female nurses: Korean Nurses' Survey. BMC Public Health. 2013;13:1204.

24. Kennaway DJ, Boden MJ, Varcoe TJ. Circadian rhythms and fertility. Mol Cell Endocrinol. 2012;349:56-61.

25. Chung FF, Yao CCC, Wan GH. The associations between menstrual function and life style/working conditions among nurses in Taiwan. J Occup Health. 2005;47:149-56.

26. McDonald AD, McDonald JC, Armstrong B, et al. Fetal death and work in pregnancy. Br J Ind Med. 1988;45:148-57.

27. Blake KR, Bastian B, O'Dean SM, et al. High estradiol and low progesterone are associated with high assertiveness in women. Psychoneuroendocrinology. 2017;75:91-9. 
28. Axelsson J, Rehman J, Akerstedt T, et al. Effects of Sustained Sleep Restriction on Mitogen-Stimulated Cytokines, Chemokines and T Helper 1/ T Helper 2 Balance in Humans. PLoS One. 2013;8:e82291.

29. Irwin M, Smith TL, Gillin JC. Electroencephalographic sleep and natural killer activity in depres-sed patients and control subjects. Psychosom Med. 1992;54:10-21.

30. Meier-Ewert HK, Ridker PM, Rifai N, et al. Effect of sleep loss on C-Reactive protein, an inflam-matory marker of cardiovascular risk. J Am Coll Cardiol. 2004;43:678-83.

31. Copertaro A, Bracci M, Gesuita R, et al. Influence of shiftwork on selected immune variables in nurses. Ind Health. 2011;49:597-604.

32. Garg SK, Maurer H, Reed K, et al. Diabetes and cancer: Two diseases with obesity as a common risk factor. Diabetes, Obes Metab. 2014;16:97-110.

33. Blaes A, Prizment A, Koene RJ, et al. Cardio-oncology Related to Heart Failure: Common Risk Factors Between Cancer and Cardiovascular Disease. Heart Fail Clin. 2017;13:367-80.

34. Bonnet MH, Arand DL. 24-Hour metabolic rate in insomniacs and matched normal sleepers. Sleep. 1995;18:581-8.
35. Banks S, Dinges DF. Behavioral and physiological consequences of sleep restriction. J Clin Sleep Med. 2007;3:519-28.

36. Dantzer R. Cytokine-induced sickness behaviour: A neuroimmune response to activation of in-nate immunity. Eur J Pharmacol. 2004;500:399-411.

37. Yang CM, Lo HS. ERP evidence of enhanced excitatory and reduced inhibitory processes of audi-tory stimuli during sleep in patients with primary insomnia. Sleep. 2007;30:585-92.

38. Burch JB, Yost MG, Johnson W, et al. Melatonin, sleep, and shift work adaptation. J Occup Envi-ron Med. 2005;47:893901.

39. Black $\mathrm{PH}$. Stress and the inflammatory response: A review of neurogenic inflammation. Brain Behav Immun. 2002;16:622-53.

40. Corcoran MP, Meydani M, Lichtenstein AH, et al. Sex hormone modulation of proinflammatory cytokine and C-reactive protein expression in macrophages from older men and postmenopau-sal women. J Endocrinol. 2010;206:217-24. 